\title{
DEMOGRAFSKA OBILJEŽJA SJEVEROZAPADNE HRVATSKE
}

\begin{abstract}
Analizirane su promjene demografskih obilježja sjeverozapadne Hrvatske pod kojom se podrazumijevaju četiri županije Međimurska, Varaždinska, Bjelovarsko-bilogorska i Koprivničkokriževačka. Obilježja se odnose na popisno kretanje (1900.-2011.), prirodno kretanje (1996.-2015.) te starosnu, spolnu i obrazovnu strukturu (1981.-2011.).
\end{abstract}

\section{UVOD}

U ovom radu analizirana su osnovna demografska obilježja sjeverozapadne Hrvatske pod kojom se podrazumijeva područje četiri županije: Koprivničkokriževačke, Krapinsko-zagorske, Međimurske i Varaždinske. Površina navedenih županija iznosi 4968 četvornih kilometara (8,8\% kopnene površine Republike Hrvatske) dok je prema popisu 2011. ovdje zabilježeno 538231 stalnih stanovnika (12,6\% ukupnog stalnog stanovništva Republike Hrvatske). Iz ovih podataka razvidno je kako se radi o iznad prosječno napučenom prostoru u hrvatskim okvirima jer relativna gustoća naseljenosti iznosi 108,3 stanovnika na četvorni kilometar dok za Hrvatsku u cjelini ona iznosi 75,7 st. $/ \mathrm{km}^{2}$. Takva naseljenost predisponirana je prirodno-geografskim značajkama prostora, povijesnim razvojem, relativnom blizinom Zagreba te povoljnim prometnim položajem.

Četiri navedene županije površinom su najmanje hrvatske županije ako se isključi Grad Zagreb koji ima poseban status. Među njima je Koprivničko-križevačka županija površinom najveća $\left(1748 \mathrm{~km}^{2}\right)$, površinom su podjednake Varaždinska (1262 $\left.\mathrm{km}^{2}\right)$ i Krapinsko-zagorska $\left(1229 \mathrm{~km}^{2}\right)$ županija dok je Međimurska županija (729 $\mathrm{km}^{2}$ ) teritorijalno najmanja.

Prema podacima popisa 2011. brojem stanovnika prednjači Varaždinska županija (175951), slijede Krapinsko-zagorska (132892), Koprivničko križevačka (115854) dok je i ovdje na začelju Međimurska županija (113804). Međutim, potonja županija 
ima najveću gustoću naseljenosti $\left(156,1\right.$ st./ $\left./ \mathrm{km}^{2}\right)$, ona je nešto manja u Varaždinskoj županiji $\left(139,4\right.$ st./ $\left./ \mathrm{km}^{2}\right)$, u Krapinsko-zagorskoj županiji identična je prosjeku SZ Hrvatske $\left(108,1\right.$ st. $\left./ \mathrm{km}^{2}\right)$ dok je u Koprivničko-križevačkoj županiji manja i od hrvatskog prosjeka $\left(66,3 \mathrm{st} . / \mathrm{km}^{2}\right)$.

\section{POPISNA PROMJENA BROJA STANOVNIKA (1900.-2011.)}

U tablici 1 prikazani su najvažniji podatci i indikatori popisnoga (brojčanog) kretanja stanovništva sjeverozapadne Hrvatske u proteklih stotinjak godina, tj. od 1900. do 2011. godine. ${ }^{1}$ Analizirano je razdoblje dovoljno dugo, a time i reprezentativno, da bi se na temelju iznesenih pokazatelja moglo zaključivati o osnovnim trendovima i procesima u demografskoj dinamici tematiziranog prostora.

Premda je demografski porast sjeverozapadne Hrvatske između 1900. i 2011. godine iznosio 8,5\% (ukupan broj stanovnika povećan je za 41946 osoba, a prosječna relativna godišnja promjena broja stanovnika je iznosila $0,08 \%$ ), već letimični pogled na prikazane podatke ukazuje na svojevrsnu vremensku i prostornu diferenciranost u popisnom kretanju broja stanovnika analiziranog područja.

Vremenska se diferenciranost očituje u nejednolikom kretanju stanovništva, pri čemu se u promatranom razdoblju (1900.-2011.) izmjenjuju međupopisja s porastom, s međupopisjima s padom ukupnoga broja stanovnika, što je ovisilo ne samo o „unutarnjim“ (demografskim) čimbenicima kretanja stanovništva, nego i o „vanjskim" odrednicama, prije svega, o modernizacijskim procesima industrijalizacije, deagrarizacije, deruralizacije i urbanizacije. Potonji su procesi naročito došli do izražaja nakon Drugoga svjetskog rata. Do tada se kretanje stanovništva odvijalo u kontekstu tradicionalnog agrarno-ruralnog prostora, s visokim stopama nataliteta i nižim stopama mortaliteta, tipičnima za prvu podetapu demografske tranzicije.

Unutar promatranog razdoblja mogu se, tako, jasno izdvojiti dva kraća i dva dulja vremenska međupopisna perioda. U prvom međupopisju (1900.-1910.) zabilježen je najveći relativni porast broja stanovnika (9,7\%), nakon toga (1910.-1921.) slijedi blaga depopulacija $(0,3 \%)$ zbog negativnih učinaka Prvoga svjetskog rata dok je između 1921. i 1953. iz popisa u popis bilježen porast broja stanovnika (ukupno 12,6\%). Upravo je 1953. godine zabilježen najveći broj stanovnika (611203) sjeverozapadne Hrvatske te nakon toga slijedi dugotrajno razdoblje (1953.-2011.) konstantnog smanjenja broja stanovnika (ukupno 11,9\%). U tih šest međupopisja najveći relativni pad (5,6\%) zabilježen je u razdoblju 2001.-2011.

\footnotetext{
S obzirom na promjene u popisnoj metodologiji, kretanje broja stanovnika sjeverozapadne Hrvatske za razdoblje 1900.-2011. godine dano je prema kriteriju "ukupnog“ stanovništva, što znači da je za relevantan uzet ukupan broj stanovnika prema metodologiji svakog pojedinog popisa (tablice 1 i 2 ).
} 
Sveukupno je između 1900. i 2011. porast iznosio 41496 stanovnika odnosno 8,5\% što je znatno manje od porasta broja stanovnika Hrvatske koji je $\mathrm{u}$ istom razdoblju iznosio $35,5 \%$. Stanovništvo sjeverozapadne Hrvatske također je u posljednjem međupopisnom razdoblju (2001.-2011.) zabilježilo veće relativno smanjenje broja stanovnika od hrvatskog prosjeka (5,6\% naspram 3,4\%). Oba podatka ukazuju da se depopulacija u sjeverozapadnoj Hrvatskoj javlja znatno ranije nego na razini čitave Hrvatske (gdje se nakon Drugog svjetskog rata prvi puta javlja između 1991. i 2001.) te da je ovdje u posljednjem međupopisju brojčano smanjenje intenzivnije od hrvatskog prosjeka.

Tablica 1. Kretanje ukupnoga broja stanovnika sjeverozapadne Hrvatske 1900.-2011. godine

\begin{tabular}{|c|c|c|c|}
\hline Godina & Broj stanovnika & $1900 .=100$ & Lančani indeks \\
\hline 1900. & 496285 & 100 & - \\
\hline 1910. & 544293 & 109,7 & 109,7 \\
\hline 1921. & 542932 & 109,4 & 99,7 \\
\hline 1931. & 575608 & 116,0 & 106,1 \\
\hline 1948. & 607519 & 122,4 & 105,5 \\
\hline 1953. & 611203 & 123,2 & 100,6 \\
\hline 1961. & 603949 & 121,7 & 98,8 \\
\hline 1971. & 600281 & 121,0 & 99,4 \\
\hline 1981. & 591677 & 119,2 & 98,6 \\
\hline 1991. & 585895 & 118,1 & 99,0 \\
\hline 2001. & 570094 & 114,9 & 97,3 \\
\hline 2011. & 538231 & 108,5 & 94,4 \\
\hline
\end{tabular}

IZVOR: Naselja i stanovništvo Republike Hrvatske 1857.-2001., Popis stanovništva 2011., Stanovništvo prema starosti i spolu po naseljima, www.dzs.hr

Kako posljednjih stotinjak godina županije sjeverozapadne Hrvatske pokazuju dijametralno različitu dinamiku kretanja broja stanovnika, u tablici 2 prikazano je popisno kretanje po županijama između 1900. i 2011. Iz tablice je također vidljivo da je najveći broj stanovnika u Koprivničko-križevačkoj županiji zabilježen 1931., u Krapinsko-zagorskoj 1948., a u Međimurskoj i Varaždinskoj 1991. godine. Također je zanimljivo da je u potonje dvije županije najmanji broj stanovnika zabilježen 1900. godine, a u Koprivničko-križevačkoj i Krapinsko-zagorskoj županiji 2011. godine. 
Tablica 2. Kretanje ukupnoga broja stanovnika sjeverozapadne Hrvatske po županijama 1900.-2011. godine

\begin{tabular}{|c|c|c|c|c|}
\hline Godina & $\begin{array}{c}\text { Koprivničko- } \\
\text { križevačka }\end{array}$ & Krapinsko-zagorska & Međimurska & Varaždinska \\
\hline 1900. & 132581 & 152047 & 79808 & 131849 \\
\hline 1910. & 142546 & 168404 & 88623 & 144720 \\
\hline 1921. & 139054 & 163594 & 92760 & 147524 \\
\hline 1931. & 143268 & 175227 & 99346 & 159767 \\
\hline 1948. & 140565 & 181586 & 110686 & 174682 \\
\hline 1953. & 142362 & 178938 & 112551 & 177352 \\
\hline 1961. & 143019 & 168952 & 112073 & 179905 \\
\hline 1971. & 138994 & 161247 & 115660 & 184380 \\
\hline 1981. & 133790 & 153567 & 116825 & 187495 \\
\hline 1991. & 129397 & 148779 & 119866 & 187853 \\
\hline 2001. & 124467 & 142432 & 118426 & 184769 \\
\hline 2011. & 115584 & 132892 & 113804 & 175951 \\
\hline
\end{tabular}

IZVOR: Kao tablica 1.

Uočljiv je disbalans i u promjeni broja stanovnika pojedinih županija po karakterističnim razdobljima; u cjelokupnom razdoblju (1900.-2011.), u razdoblju nakon Drugog svjetskog rata (1948.-2011.) te u posljednjem međupopsinom razdoblju (2001.-2011.). Tako je u cjelokupnom razdoblju (1900.-2011.) ukupan broj stanovnika SZ Hrvatske povećan 8,5\% (tablica 1) dok su Koprivničko-križevačka i Krapinskozagorska županija imale gotovo identično smanjenje od 13-ak posto (tablica 2). Nasuprot njima, u istom razdoblju Varaždinska županija povećala je broj stanovnika za trećinu, a Međimurska županija za čak 42,6\%. U drugom karakterističnom razdoblju (1948.-2011.) ukupan broj stanovnika sjeverozapadne Hrvatske smanjen je $11,4 \%$. U Krapinsko-zagorskoj županiji to je smanjenje znatno intenzivnije (26,8\%), a u Koprivničko-križevačkoj nešto blaže, ali još uvijek veće $(17,8 \%)$ od prosjeka čitavog promatranog područja. Nasuprot njima, stanovništvo Varaždinske županije zabilježilo je blagi brojčani porast $(0,7 \%)$ dok Međimurska županija ponovno prednjači s pozitivnim demografskim procesom (porast od 2,8\%). U posljednjem promatranom razdoblju (2001.-2011.) sve cjeline bilježe pad broja stanovnika s time da Koprivničkokriževačka (-7,1\%) i Krapinsko-zagorska županija (-6,7\%) ponovno imaju relativno veće smanjenje od prosjeka SZ Hrvatske $(-5,2 \%)$, dok druge dvije županije bilježe nešto blaže smanjenje; -3,9\% Međimurska odnosno -4,8\% Varaždinska županija. 
Tablica 3. Promjena broja stanovnika sjeverozapadne Hrvatske i njezinih županija u razdobljima 1900.-2011, 1948.-2011. te 2001.-2011. godine

\begin{tabular}{|l|c|c|c|}
\hline \multirow{2}{*}{ Područje } & \multicolumn{3}{|c|}{ Indeks promjene broja stanovnika } \\
\cline { 2 - 4 } & $2011 . / 1900$. & $2011 . / 1948$. & $2011 . / 2001$. \\
\hline Koprivničko-križevačka ž. & 87,2 & 82,2 & 92,9 \\
\hline Krapinsko-zagorska ž. & 87,4 & 73,2 & 93,3 \\
\hline Međimurska ž. & 142,6 & 102,8 & 96,1 \\
\hline Varaždinska ž. & 133,4 & 100,7 & 95,2 \\
\hline SZ Hrvatska & 108,5 & 88,6 & 94,4 \\
\hline
\end{tabular}

IZVOR: tablice 1 i 2

\section{PRIRODNO KRETANJE STANOVNIŠTVA (1996.-2015.)}

Prirodno kretanje stanovništva sjeverozapadne Hrvatske prikazano je i ukratko opisano za razdoblje između 1996. i 2015. godine. U tih dvadeset godina prirodnim je putem izgubljeno 34998 osoba odnosno 6\% u odnosu na broj stanovnika sjeverozapadne Hrvatske iz popisa 1991. godine. Najveći broj živorođenih zabilježen je prve dvije promatrane godine (1996. i 1997.), a najmanji broj posljednje dvije godine (2014. i 2015.) s time da je 2015. broj živorođenih čak za 1810 osoba (27,8\%) manji nego 1996. To smanjenje može se predočiti na način da će u odnosu na generaciju djece rođenih 1996. za koju godinu tj. kada rođeni 2015. godine krenu u osnovnu školu, u sjeverozapadnoj Hrvatskoj biti upisano 72 razreda manje (s 25 učenika). Što se tiče broja umrlih, on je svih godina bio barem za tisuću veći od broja živorođenih dok je prirodni pad bio najdublji 2015. godine (2399 osoba). Zapaža se i da je nakon te godine najveći apsolutni prirodni pad zabilježen između 2002. i 2004. što se djelomično može objasniti smanjenjem roditeljske naknade (za vrijeme roditeljskog dopusta između 6. i 12. mjeseca djetetovog života) s maksimalnih 2.500,00 na $1.600,00$ kuna. 
Tablica 4. Prirodno kretanje stanovništva sjeverozapadne Hrvatske 1996.-2015. godine

\begin{tabular}{|c|c|c|c|}
\hline Godina & Živorođeni & Umrli & Prirodna promjena \\
\hline 1996. & 6521 & 7594 & -1073 \\
\hline 1997. & 6530 & 7703 & -1173 \\
\hline 1998. & 6169 & 7744 & -1575 \\
\hline 1999. & 5956 & 7597 & -1641 \\
\hline 2000. & 5760 & 7418 & -1658 \\
\hline 2001. & 5563 & 7260 & -1697 \\
\hline 2002. & 5390 & 7403 & -2013 \\
\hline 2003. & 5252 & 7598 & -2346 \\
\hline 2004 & 5226 & 7166 & -1940 \\
\hline 2005. & 5537 & 7052 & -1515 \\
\hline 2006 & 5315 & 7039 & -1724 \\
\hline 2007. & 5298 & 7183 & -1885 \\
\hline 2008 & 5530 & 7381 & -1851 \\
\hline 2009. & 5578 & 7269 & -1691 \\
\hline 2010. & 5457 & 7118 & -1661 \\
\hline 2011. & 5134 & 6915 & -1781 \\
\hline 2012. & 5130 & 6913 & -1783 \\
\hline 2013. & 4985 & 6719 & -1734 \\
\hline 2014. & 4845 & 6703 & -1858 \\
\hline 2015. & 4711 & 7110 & -2399 \\
\hline UKUPNO & 109887 & 144885 & -34998 \\
\hline
\end{tabular}

IZVOR: Prirodno kretanje stanovništva Republike Hrvatske, Tablogrami po naseljima, DZS.

Za razliku od apsolutnih brojeva, mnogo su bolji pokazatelji stope prirodnog kretanja po kojima je vidljivo da su stope nataliteta, a koje su početne dvije godine bile veće od 11 promila, znatno smanjene pa je 2015. zabilježena stopa od svega 9 promila što se općenito smatra izuzetno niskom stopom. Stope mortaliteta su pak u cjelokupnom razdoblju relativno visoke te se kreću između 12,6 i 13,5 promila. Stopa prirodne promjene najnegativnija je 2015. godine, a izrazito nepovoljne stope zabilježene su i u ranije spomenutom razdoblju 2002.-2004. te nakon u razdoblju 2007.-2014. godine. 
Tablica 5. Stope prirodnog kretanja stanovništva sjeverozapadne Hrvatske 1996.-2015. godine

\begin{tabular}{|c|c|c|c|}
\hline Godina & Živorođeni & Umrli & Prirodna promjena \\
\hline 1996. & 11,3 & 13,1 & $-1,8$ \\
\hline 1997. & 11,3 & 13,4 & $-2,1$ \\
\hline 1998. & 10,7 & 13,5 & $-2,8$ \\
\hline 1999. & 10,4 & 13,3 & $-2,9$ \\
\hline 2000. & 10,1 & 13,0 & $-2,9$ \\
\hline 2001. & 9,8 & 12,7 & $-2,9$ \\
\hline 2002. & 9,5 & 13,1 & $-3,6$ \\
\hline 2003. & 9,3 & 13,5 & $-4,2$ \\
\hline 2004. & 9,3 & 12,8 & $-3,3$ \\
\hline 2005. & 9,9 & 12,7 & $-2,8$ \\
\hline 2006. & 9,6 & 12,7 & $-3,1$ \\
\hline 2007. & 9,6 & 13,0 & $-3,4$ \\
\hline 2008. & 10,1 & 13,5 & $-3,4$ \\
\hline 2009. & 10,2 & 13,3 & $-3,1$ \\
\hline 2010. & 10,1 & 13,1 & $-3,0$ \\
\hline 2011. & 9,5 & 12,8 & $-3,3$ \\
\hline 2012. & 9,6 & 12,9 & $-3,3$ \\
\hline 2013. & 9,4 & 12,6 & $-3,2$ \\
\hline 2014. & 9,2 & 12,7 & $-3,5$ \\
\hline 2015. & 9,0 & 13,5 & $-4,5$ \\
\hline
\end{tabular}

IZVOR: Izračun autora prema podacima u tablici 4 i procjeni broja stanovnika za svaku godinu

U tablicama 6-9 prikazani su apsolutni iznosi i stope nataliteta, mortaliteta te prirodne promjene za svaku županiju po pojedinim godinama između 1996. i 2015. Krapinsko-zagorska županija u promatranom razdoblju svih godina bilježi prirodni pad te je zabilježila ukupno prirodno smanjenje od 14137 osoba ili čak 9,5\% županijskog stanovništva iz popisa 1991. Između dviju odrednica prirodnog kretanja, znatno su veće promjene zabilježene u broju živorođenih jer njihovo smanjenje između prve i posljednje godine (koje su ujedno i godine s najvećim tj. najmanjim brojem živorođenih) iznosi 511 djece odnosno 2015. je rođeno točno trećina djece manje nego 1996. Stoga je u istom razdoblju stopa nataliteta pala sa $10,6 \%$ na svega $8 \%$. Broj umrlih nije se mijenjao u tolikoj mjeri pa je stopa mortaliteta oscilirala između $13,7 \%$ o i $14,4 \%$. 
Tablica 6. Prirodno kretanje stanovništva Krapinsko-zagorske županije 1996.-2015. godine

\begin{tabular}{|c|c|c|c|c|c|c|}
\hline & \multicolumn{3}{|c|}{ Apsolutni broj } & \multicolumn{3}{c|}{ Stopa u \%o } \\
\cline { 2 - 7 } Godina & živorođeni & umrli & $\begin{array}{c}\text { prirodna } \\
\text { promjena }\end{array}$ & natalitet & mortalitet & $\begin{array}{c}\text { prirodna } \\
\text { promjena }\end{array}$ \\
\hline 1996. & 1548 & 2084 & -536 & 10,6 & 14,3 & $-3,7$ \\
\hline 1997. & 1502 & 2138 & -636 & 10,4 & 14,7 & $-4,3$ \\
\hline 1998. & 1519 & 2104 & -585 & 10,5 & 14,6 & $-3,9$ \\
\hline 1999. & 1417 & 2084 & -667 & 9,9 & 14,5 & $-4,6$ \\
\hline 2000. & 1354 & 2006 & -652 & 9,5 & 14,0 & $-4,5$ \\
\hline 2001. & 1227 & 2051 & -824 & 8,6 & 14,4 & $-5,8$ \\
\hline 2002. & 1296 & 2039 & -748 & 9,2 & 14,4 & $-5,2$ \\
\hline 2003. & 1216 & 2126 & -910 & 8,7 & 15,1 & $-6,4$ \\
\hline 2004. & 1224 & 1973 & -749 & 8,8 & 14,1 & $-5,3$ \\
\hline 2005. & 1228 & 1905 & -677 & 8,9 & 13,7 & $-4,8$ \\
\hline 2006. & 1204 & 1916 & -712 & 8,7 & 13,9 & $-5,2$ \\
\hline 2007. & 1206 & 1929 & -722 & 8,8 & 14,1 & $-5,3$ \\
\hline 2008. & 1285 & 2004 & -719 & 9,5 & 14,8 & $-5,3$ \\
\hline 2009. & 1282 & 1987 & -705 & 9,5 & 14,7 & $-5,2$ \\
\hline 2010. & 1265 & 1916 & -651 & 9,5 & 14,3 & $-4,8$ \\
\hline 2011. & 1179 & 1867 & -688 & 8,9 & 14,0 & $-5,1$ \\
\hline 2012. & 1190 & 1898 & -708 & 9,0 & 14,4 & $-5,4$ \\
\hline 2013. & 1152 & 1882 & -730 & 8,8 & 14,4 & $-5,6$ \\
\hline 2014. & 1153 & 1868 & -715 & 8,9 & 14,4 & $-5,5$ \\
\hline 2015. & 1037 & 1844 & -807 & 8,0 & 14,3 & $-6,3$ \\
\hline UKUPNO & 25484 & 39621 & -14137 & - & - & - \\
\hline & & & & & & \\
\hline
\end{tabular}

IZVOR: Prirodno kretanje stanovništva Republike Hrvatske, Tablogrami po naseljima, DZS i autorski izračun stopa prema procjeni broja stanovnika za svaku godinu.

I u Koprivničko-križevačkoj županiji svih je godina zabilježen prirodni pad te je na taj način izgubljeno 10268 stanovnika ili 10,9\% stanovništva u odnosu na popis 1991. Također je zabilježen sličan trend i u kretanju nataliteta te mortaliteta kao i u Krapinsko-zagorskoj županiji. Broj živorođenih i ovdje je bio najveći 1996., a najmanji 2015. godine dok je njihovo apsolutno smanjenje između te dvije godine iznosilo 30,6\%. Razlika u krajnjim vrijednostima stopa nataliteta još je veća nego kod Krapinsko-zagorske županije; kretala se između 11,5\% i 7,8\%o. Kod stopa mortaliteta te su razlike znatno manje; kreću se između 14,8\%o i 12,8\% što je ipak znatnija oscilacija nego kod Krapinsko-zagorske županije. 
Tablica 7. Prirodno kretanje stanovništva Koprivničko-križevačke županije 1996.-2015. godine

\begin{tabular}{|c|c|c|c|c|c|c|}
\hline & \multicolumn{3}{|c|}{ Apsolutni broj } & \multicolumn{3}{c|}{ Stopa u \%o } \\
\cline { 2 - 7 } Godina & živorođeni & umrli & $\begin{array}{c}\text { prirodna } \\
\text { promjena }\end{array}$ & natalitet & mortalitet & $\begin{array}{c}\text { prirodna } \\
\text { promjena }\end{array}$ \\
\hline 1996. & 1456 & 1872 & -416 & 11,5 & 14,7 & $-3,9$ \\
\hline 1997. & 1427 & 1856 & -429 & 11,3 & 14,7 & $-4,0$ \\
\hline 1998. & 1352 & 1803 & -451 & 10,7 & 14,3 & $-3,6$ \\
\hline 1999. & 1263 & 1797 & -534 & 10,1 & 14,3 & $-4,2$ \\
\hline 2000. & 1208 & 1754 & -546 & 9,7 & 14,0 & $-4,3$ \\
\hline 2001. & 1200 & 1706 & -506 & 9,6 & 13,7 & $-4,1$ \\
\hline 2002. & 1168 & 1724 & -556 & 9,5 & 14,0 & $-4,5$ \\
\hline 2003. & 1104 & 1708 & -604 & 9,0 & 13,9 & $-4,9$ \\
\hline 2004. & 1099 & 1738 & -639 & 9,0 & 14,3 & $-5,3$ \\
\hline 2005. & 1239 & 1694 & -455 & 10,2 & 14,0 & $-3,8$ \\
\hline 2006. & 1127 & 1702 & -575 & 9,4 & 14,2 & $-4,8$ \\
\hline 2007. & 1157 & 1709 & -552 & 9,7 & 14,3 & $-4,6$ \\
\hline 2008. & 1232 & 1751 & -519 & 10,4 & 14,8 & $-4,4$ \\
\hline 2009. & 1190 & 1721 & -531 & 10,1 & 14,7 & $-4,6$ \\
\hline 2010. & 1173 & 1673 & -500 & 10,1 & 14,4 & $-4,3$ \\
\hline 2011. & 1108 & 1607 & -499 & 9,6 & 13,9 & $-4,3$ \\
\hline 2012. & 1092 & 1575 & -483 & 9,5 & 13,7 & $-4,2$ \\
\hline 2013. & 1113 & 1456 & -343 & 9,8 & 12,8 & $-3,0$ \\
\hline 2014. & 1059 & 1573 & -514 & 9,4 & 13,9 & $-4,5$ \\
\hline 2015. & 1010 & 1626 & -616 & 7,8 & 14,5 & $-6,7$ \\
\hline UKUPNO & 23777 & 34045 & -10268 & - & - & - \\
\hline
\end{tabular}

IZVOR: Prirodno kretanje stanovništva Republike Hrvatske, Tablogrami po naseljima, DZS i autorski izračun stopa prema procjeni broja stanovnika za svaku godinu.

Međimurska županija ima sasvim drugačija obilježja prirodnog kretanja stanovništva od prethodne dvije županije. Naime, ovdje je promatranih dvadeset godina prirodni pad iznosio svega 196 stanovnika ili 1,6\% ukupnog stanovništva iz 1991. godine. Razlika je i u tome što prirodni pad nije bilježen u cjelokupnom razdoblju nego $u$ deset promatranih godina $i$ to $u$ nepravilnim razmacima. Zanimljivo je i da su ovdje najveći brojevi živorođenih i najveće stope nataliteta bilježene početne dvije godine, no njihov najmanji broj (kao i stopa) nije zabilježen 2015. nego 2004. godine. Između sve četiri županije stope nataliteta pokazuju najmanje oscilacije (između $10,1 \%$ o i $12,3 \%$ ), a stope mortaliteta još i manje (između 10,4\%o i 11,4\%o). 
Tablica 8. Prirodno kretanje stanovništva Međimurske županije 1996.-2015. godine

\begin{tabular}{|c|c|c|c|c|c|c|}
\hline & \multicolumn{3}{|c|}{ Apsolutni broj } & \multicolumn{3}{c|}{ Stopa u \%o } \\
\cline { 2 - 7 } Godina & živorođeni & umrli & $\begin{array}{c}\text { prirodna } \\
\text { promjena }\end{array}$ & natalitet & mortalitet & $\begin{array}{c}\text { prirodna } \\
\text { promjena }\end{array}$ \\
\hline 1996. & 1440 & 1306 & 134 & 12,1 & 11,0 & 1,1 \\
\hline 1997. & 1461 & 1345 & 116 & 12,3 & 11,3 & 1,0 \\
\hline 1998. & 1314 & 1351 & -37 & 11,1 & 11,4 & $-0,3$ \\
\hline 1999. & 1346 & 1333 & 13 & 11,3 & 11,2 & 0,1 \\
\hline 2000. & 1345 & 1287 & 58 & 11,3 & 10,9 & 0,4 \\
\hline 2001. & 1346 & 1237 & 109 & 11,4 & 10,4 & 1,0 \\
\hline 2002. & 1238 & 1311 & -73 & 10,5 & 11,1 & $-0,6$ \\
\hline 2003. & 1249 & 1272 & -22 & 10,6 & 10,8 & $-0,2$ \\
\hline 2004. & 1178 & 1210 & -32 & 10,1 & 10,3 & $-0,2$ \\
\hline 2005. & 1236 & 1254 & -16 & 10,6 & 10,8 & $-0,2$ \\
\hline 2006. & 1220 & 1296 & -76 & 10,5 & 11,2 & $-0,7$ \\
\hline 2007. & 1214 & 1229 & -15 & 10,5 & 10,6 & $-0,1$ \\
\hline 2008. & 1286 & 1272 & 14 & 11,2 & 11,0 & 0,2 \\
\hline 2009. & 1326 & 1281 & 45 & 11,6 & 11,2 & 0,4 \\
\hline 2010. & 1286 & 1235 & 51 & 11,3 & 10,8 & 0,5 \\
\hline 2011. & 1253 & 1254 & -1 & 11,0 & 11,0 & 0,0 \\
\hline 2012. & 1205 & 1189 & 16 & 10,6 & 10,5 & 0,1 \\
\hline 2013. & 1201 & 1227 & -26 & 10,6 & 10,9 & $-0,3$ \\
\hline 2014. & 1174 & 1168 & 6 & 10,4 & 10,4 & 0,0 \\
\hline 2015. & 1209 & 1274 & -65 & 10,8 & 11,4 & $-0,6$ \\
\hline UKUPNO & 25527 & 25331 & -196 & - & - & - \\
\hline
\end{tabular}

IZVOR: Prirodno kretanje stanovništva Republike Hrvatske, Tablogrami po naseljima, DZS i autorski izračun stopa prema procjeni broja stanovnika za svaku godinu.

Varaždinska županija u svim godinama bilježila je više umrlih nego živorođenih što je u dvadesetogodišnjem razdoblju rezultiralo prirodnim padom od 10789 osoba (5,7\% stanovništva iz 1991.). Premda je u apsolutnom iznosu to nešto više od prirodnog pada Koprivničko-križevačke županije, potonja je zbog ukupno malobrojnijeg stanovništva, prirodnim putem izgubila gotovo dvostruko više stanovnika od Varaždinske županije u odnosu na broj žitelja iz 1991. godine. I u ovoj županiji došlo je do drastičnog pada broja živorođenih između krajnjih godina pa je tako 2015. godine rođeno 32\% manje djece nego 1997. kada ih je rođeno najviše u promatranom razdoblju. Stoga je i ovdje došlo do drastičnog smanjenja stopa nataliteta između 
godina s najvećim i najmanjim brojem rođenih (sa $11,5 \%$ na $8,4 \%$ ). Posljednje godine (2015.) zabilježena je uvjerljivo najveća stopa prirodnog pada $(5,3 \%$ o) te je samo te godine ova županija prirodnim putem izgubila gotovo tisuću stanovnika.

Tablica 9. Prirodno kretanje stanovništva Varaždinske županije 1996.-2015. godine

\begin{tabular}{|c|c|c|c|c|c|c|}
\hline & \multicolumn{3}{|c|}{ Apsolutni broj } & \multicolumn{3}{c|}{ Stopa u \%o } \\
\cline { 2 - 7 } Godina & živorođeni & umrli & $\begin{array}{c}\text { prirodna } \\
\text { promjena }\end{array}$ & natalitet & mortalitet & $\begin{array}{c}\text { prirodna } \\
\text { promjena }\end{array}$ \\
\hline 1996. & 2077 & 2332 & -255 & 11,1 & 12,5 & $-0,4$ \\
\hline 1997. & 2140 & 2364 & -224 & 11,5 & 12,7 & $-0,2$ \\
\hline 1998. & 1984 & 2486 & -502 & 10,7 & 13,4 & $-2,7$ \\
\hline 1999. & 1930 & 2383 & -453 & 10,4 & 12,9 & $-2,5$ \\
\hline 2000. & 1853 & 2371 & -518 & 10,0 & 12,8 & $-2,8$ \\
\hline 2001. & 1790 & 2266 & -476 & 9,7 & 12,3 & $-2,6$ \\
\hline 2002. & 1688 & 2329 & -641 & 9,2 & 12,7 & $-3,5$ \\
\hline 2003. & 1683 & 2492 & -809 & 9,2 & 13,6 & $-4,4$ \\
\hline 2004. & 1725 & 2245 & -520 & 9,5 & 12,3 & $-2,8$ \\
\hline 2005. & 1834 & 2199 & -365 & 10,1 & 12,1 & $-2,0$ \\
\hline 2006. & 1764 & 2125 & -361 & 9,8 & 11,8 & $-2,0$ \\
\hline 2007. & 1721 & 2316 & -595 & 9,6 & 12,9 & $-3,3$ \\
\hline 2008. & 1727 & 2354 & -627 & 9,7 & 13,2 & $-3,5$ \\
\hline 2009. & 1780 & 2280 & -500 & 10,0 & 12,8 & $-2,8$ \\
\hline 2010. & 1733 & 2294 & -561 & 9,8 & 13,0 & $-3,2$ \\
\hline 2011. & 1594 & 2187 & -593 & 9,1 & 12,4 & $-3,3$ \\
\hline 2012. & 1643 & 2251 & -608 & 9,4 & 12,9 & $-3,5$ \\
\hline 2013. & 1519 & 2154 & -635 & 8,7 & 12,4 & $-3,7$ \\
\hline 2014. & 1459 & 2094 & -635 & 8,4 & 12,1 & $-3,7$ \\
\hline 2015. & 1455 & 2366 & -911 & 8,4 & 13,7 & $-5,3$ \\
\hline UKUPNO & 35099 & 45888 & -10789 & - & - & - \\
\hline & & & & & & \\
\hline
\end{tabular}

IZVOR: Prirodno kretanje stanovništva Republike Hrvatske, Tablogrami po naseljima, DZS i autorski izračun stopa prema procjeni broja stanovnika za svaku godinu.

Izrazito nepovoljne tendencije u prirodnom kretanju očituju se npr. i u podatku da je 2015. godine prirodni pad zabilježen u čak 99 od ukupno 110 gradova i općina sjeverozapadne Hrvatske. Više rođenih od umrlih te je godine zabilježen samo u gradovima Čakovec i Mursko Središće te općinama Jesenje, Mala Subotica, Nedelišće, 
Novi Golubovec, Petrijanec, Podturen, Pribislavec, Selnica i Sveti Juraj na Bregu. Većina tih jedinica bilježi prirodni prirast zbog relativno velikog broja stanovnika romske narodnosti, a koji imaju znatno veće stope nataliteta od ostalih stanovnika.

\section{SASTAV STANOVNIŠTVA SJEVEROZAPADNE HRVATSKE PREMA DOBI I SPOLU}

Među brojnim strukturama stanovništva najvažnijom se u demografskoj literaturi i teoriji smatra struktura prema spolu i dobi. Značenje te strukture za prošla, trenutna i naročito buduća demografska kretanja i trendove proizlazi ponajviše iz činjenice da ona predstavlja osnovni i najvažniji demografski okvir za formiranje reproduktivnih (fertilnih) i radno-sposobnih kontingenata neke populacije, čime izravno determinira razinu njezine reprodukcije (nataliteta/fertiliteta) kao i njezine ekonomske aktivnosti (Wertheimer-Baletić, 1999.).

Eventualni poremećaji u međuodnosu između velikih i funkcionalnih dobnih skupina mogu u dugoročnom smislu izazvati značajne poteškoće u prirodnom, a time i u ukupnom kretanju stanovništva, ali i u ekonomskom razvoju koji, među ostalim, ovisi o ponudi i strukturi radne snage. Manjak radne snage, izazvan sužavanjem mladih i radno-sposobnih kontingenata stanovništva, usporit će ekonomski razvoj te može potaknuti novo doseljavanje.

Uz migracije i "eksterne“, odnosno neregularne uvjete razvoja (primjerice, ratove), na razvoj dobnog i spolnog sastava stanovništva najviše utječu natalitet $i$ mortalitet. Visina nataliteta/fertiliteta izravno determinira priljev stanovništva $u$ dječju i mladu, a time kasnije i u fertilnu, odnosno, radno-sposobnu dob. Nizak natalitet i negativno prirodno kretanje stanovništva remetilačke su odrednice razvoja dobnog sastava stanovništva, okrnjuju njegovu piramidu starosti te ubrzavaju proces demografskog starenja.

U takvim uvjetima starenje stanovništva neumitan je proces i u sjeverozapadnoj Hrvatskoj. Precizno ga za razdoblje 1981.-2011. godine indiciraju tri pokazatelja: pad koeficijenta mladosti (sa 28,8 na 21,6), porast koeficijenta starosti (sa 16,2 na 22,8 ) te porast indeksa starenja (sa 56,4 na 105,8). Upravo potonji indikator ukazuje na dosegnuti stupanj demografskog starenja (u demografskoj se literaturi indeks starenja 40,0 smatra graničnom vrijednošću koja omeđuje mladu od stare populacije), ali i na činjenicu da sjeverozapadna Hrvatska - u cjelini uzevši - ima nešto mlađu populaciju od hrvatskoga prosjeka (naime, indeks starenja ukupnog stanovništva Hrvatske za 2011. godinu iznosi 115.

Valja naglasiti da su (negativne) promjene $\mathrm{u}$ dobno-spolnoj strukturi stanovništva Hrvatske nastavak dosadašnjih tendencija povećanja disproporcije između 
velikih dobnih grupa, što ima dugoročne i vrlo nepovoljne posljedice po demografski, društveni i gospodarski razvoj Hrvatske (Živić, Pokos i Turk 2005).

Proces starenja stanovništva donekle ilustrira i promjena broja stanovnika prema velikim dobnim skupinama. Tako je između 2001. i 2011. godine, kada je broj ukupnog stanovništva sjeverozapadne Hrvatske smanjen 5,6\%, broj mladog stanovništva (do 19. godine starosti) smanjen 16,1\%, broj zrelog stanovništva (od 20. do 59. godine starosti) smanjen je 3,3\%, a broj starog stanovništva (60 godina i stariji) povećan $1,9 \%$.

Tablica 10. Velike dobne skupine stanovništva sjeverozapadne Hrvatske 1981.-2011. godine

\begin{tabular}{|c|c|c|c|c|c|c|c|}
\hline Godina & $0-19$ & $\%$ & $20-59$ & $\%$ & 60 i više & $\%$ & $\begin{array}{c}\text { Indeks } \\
\text { starenja }\end{array}$ \\
\hline 1981. & 170274 & 28,8 & 321572 & 54,4 & 96011 & 16,2 & 56,4 \\
\hline 1991. & 155265 & 26,5 & 316387 & 54,0 & 109086 & 18,6 & 70,3 \\
\hline 2001. & 138497 & 24,3 & 309290 & 54,3 & 120654 & 21,2 & 87,1 \\
\hline 2011. & 116214 & 21,6 & 299086 & 55,6 & 122930 & 22,8 & 105,8 \\
\hline
\end{tabular}

* Razlika do ukupnog broja stanovnika 1981., 1991. i 2001. odnosi se na stanovništvo nepoznate starosti. U rezultatima popisa 2011. nema stanovništva nepoznate starosti.

IZVOR: Popis stanovništva 1981. Tabele po naseljima, RZS, Zagreb, 1982. Popis stanovništva 1991. Stanovništvo prema spolu i starosti po naseljima, Dokumentacija 882. DZS, Zagreb, 1994. Popis stanovništva 2001. Stanovništvo prema spolu i starosti po naseljima, Statističko izvješće 1167, DZS, Zagreb, 2003. Popis stanovništva 2011. Stanovništvo prema starosti i spolu, www.dzs.hr

Analiza indeksa starenja po županijama (tablica 11) također potvrđuje demografsko starenje kao vodeći proces u razvoju dobnog i spolnog sastava stanovništva toga kraja. Sve su županije već 1981. godine imale indeks starenja veći od 40,0 najniži je bio u Međimurskoj županiji $(44,2)$, slijedile su Varaždinska županija $(50,9)$ i Krapinsko zagorska županija $(62,4)$ dok je najviši indeks starenja zabilježen u Koprivničko-križevačkoj županiji $(70,5)$. Isti redoslijed javlja se i 1991. godine, ali sa znatno većim stupnjem ostarjelosti stanovništva u svim županijama. Godine 2001. dolazi do promjene jer najstarije stanovništvo više nema Koprivničko-križevačka već Krapinsko-zagorska županija, a u obje županije indeks starenja tek je nešto manji od 100 odnosno gotovo je izjednačen broj mladih i starih stanovnika. Posljednjim popisom iz 2011. jedino Međimurska županija još uvijek nije imala više starih od mladih, a indeks starenja stanovništva Varaždinske županije sasvim se približio indeksima u Krapinsko-zagorskoj i Koprivničko-križevačkoj županiji.

Sa stajališta demoreprodukcije sve županije imaju vrlo negativan odnos koji zapravo znači sužavanje biodinamičke i demografske osnovice s predvidivim 
nepovoljnim učincima na buduća demografska kretanja u tom naselju, naročito dinamiku nataliteta/fertiliteta. Najmlađi dobni sastav stanovništva Međimurske županije uglavnom je posljedica relativno povoljnijeg prirodnog kretanja stanovništva premda je i tamo broj i udjel mladog i starog stanovništva gotovo izjednačen što je uočljivo na smanjenju razine rodnosti stanovništva posljednjih dvadesetak godina (tablica 8).

Tablica 11. Indeksi starenja stanovništva sjeverozapadne Hrvatske po županijama 1981.-2011. godine

\begin{tabular}{|l|c|c|c|c|}
\hline \multirow{2}{*}{ Županija } & \multicolumn{3}{|c|}{ Indeks starenja } \\
\cline { 2 - 5 } & 1981. & 1991. & 2001. & 2011. \\
\hline Koprivničko-križevačka ž. & 70,5 & 81,7 & 94,4 & 110,5 \\
\hline Krapinsko-zagorska ž. & 62,4 & 78,3 & 94,7 & 112,6 \\
\hline Međimurska ž. & 44,2 & 56,3 & 71,9 & 91,8 \\
\hline Varaždinska ž. & 50,9 & 66,5 & 87,0 & 107,3 \\
\hline
\end{tabular}

IZVOR: Kao tablica 10.

Struktura stanovništva prema spolu općenito je determinirana diferencijalnim natalitetom po spolu, diferencijalnim mortalitetom po spolu te selektivnim migracijama po spolu. To, drugim riječima, znači da će spolni sastav ovisiti o odnosu između broja muške i ženske živorođene djece, o odnosu između broja umrlih muškaraca i žena te o odnosu između broja muških i ženskih migranata. Opće je poznato da se $5 \%$ do $7 \%$ više rađa muške nego ženske djece, i kada bi samo ta zakonitost određivala spolnu strukturu onda bismo u bilo kojoj populaciji uvijek imali više muškaraca od žena. No, to nije tako, jer muškarci „dobitak“ pri rođenju gube već u zrelim i naročito starijim dobnim skupinama. Razlog feminizacije starijih dobnih skupina posljedica je veće smrtnosti muškaraca, većega stradanja muškaraca u sva tri rata prošloga stoljeća te selektivne emigracije po spolu, jer se iz Hrvatske više iseljavalo muško stanovništvo (Peračković i Pokos, 2015.).

Tablica 12. Broj muškaraca i žena u sjeverozapadnoj Hrvatskoj 1981.-2011. godine

\begin{tabular}{|c|c|c|c|}
\hline Godina & Broj muškaraca & Broj žena & Koeficijent feminiteta \\
\hline 1981. & 288488 & 303189 & 105,1 \\
\hline 1991. & 285107 & 300788 & 105,5 \\
\hline 2001. & 277413 & 292681 & 105,5 \\
\hline 2011. & 261859 & 276372 & 105,5 \\
\hline
\end{tabular}


Svih promatranih godina u sjeverozapadnoj Hrvatskoj na 100 muškaraca dolazilo je nešto više od 105 žena što je uvijek bilo manje od hrvatskog koeficijenta feminiteta koji je npr. 1981. iznosio 106,6, a 2011. kao posljednje promatrane godine 107,3. Razlozi tome su starija dobna struktura stanovništva Hrvatske, veći gubici muškog stanovništva $u$ ratovima na državnoj razini te vjerojatno intenzivnije iseljavanje muškog stanovništva iz države nego iz sjeverozapadne Hrvatske.

Zanimljivo je da se koeficijent feminiteta stanovništva sjeverozapadne Hrvatske tek neznatno smanjio između 1981. i 1991., a da se uopće nije mijenjao između 1991. i 2011. godine. Ovu pojavu nije moguće u potpunosti objasniti zbog nepoznatih podataka o spolnoj strukturi doseljenih i iseljenih stanovnika u/iz sjeverozapadne Hrvatske. Međutim, u rasvjetljavanju te slike donekle mogu pomoći podaci o spolnoj strukturi pojedinih županija prikazani u tablici 13. Uvjerljivo najveći disbalans 1981. godine imala je Koprivničko-križevačka županija gdje je koeficijent feminiteta iznosio 108,4. To je donekle i razumljivo jer je te godine Koprivničko-križevačka županija imala najstarije stanovništvo, a ranije je navedeno da se višak žena pogotovo javlja u starijim dobnim skupinama. Pretpostavljajući da se u svim županijama rađalo podjednako više dječaka nego djevojčica te da su sve županije bile zahvaćene intenzivnim procesom starenja, smanjenje koeficijenta feminiteta u Koprivničko-križevačkoj županiji nakon 1981. može se protumačiti jedino većim stopama iseljavanja ženskog stanovništva. Nasuprot tome, u Krapinsko-zagorskoj županiji nakon 1981. dolazi do porasta koeficijenta feminiteta što je posljedica jačeg procesa starenja u toj županiji zbog čega 2001. godine ovdje živi najstarije stanovništvo u sjeverozapadnoj Hrvatskoj. Zbog relativno najmlađeg stanovništva, u Međimurskoj županiji svih godina zabilježen je najmanji koeficijent feminiteta premda je postupno do 2011. godine i ovdje došlo do relativno jačeg disbalansa spolne strukture. Svakako je tome glavni razlog starenje stanovništva, ali moguće je i da su muškarci iseljavali u većoj mjeri od žena. U cjelokupnom razdoblju tek nešto blaži porast koeficijenta feminiteta zabilježen je i u Varaždinskoj županiji premda u razdoblju 2001.-2011. dolazi do njegovog smanjenja što se pak može tumačiti jedino jačom stopom iseljavanja žena od muškaraca.

Tablica 13. Koeficijenti feminiteta stanovništva sjeverozapadne Hrvatske po županijama 1981.-2011.

\begin{tabular}{|l|l|l|l|l|}
\hline \multirow{2}{*}{ Županija } & \multicolumn{3}{|c|}{ Koeficijent feminiteta } \\
\cline { 2 - 5 } & 1981. & 1991. & 2001. & 2011. \\
\hline Koprivničko-križevačka ž. & 108,4 & 107,9 & 107,0 & 106,5 \\
\hline Krapinsko-zagorska ž. & 103,6 & 104,4 & 105,2 & 105,6 \\
\hline Međimurska ž. & 103,1 & 104,3 & 104,0 & 104,7 \\
\hline Varaždinska ž. & 105,2 & 105,5 & 105,7 & 105,4 \\
\hline
\end{tabular}

Kao tablica 10. 


\section{STANOVNIŠTVO SJEVEROZAPADNE HRVATSKE PREMA NAOBRAZBI}

Prosječna je naobrazba stanovništva sjeverozapadne Hrvatske, u odnosu na Hrvatsku u cijelosti, signifikantno lošija, što se posebno odnosi na vrlo nizak broj i udio stanovništva sa završenim visokim obrazovanjem. ${ }^{2}$ Udio te kategorije u ukupnom stanovništvu sjeverozapadne Hrvatske starijem od 15. godine, prema popisu iz 2011. godine, iznosio je svega 10,6\% ( $\mathrm{RH}-16,4 \%$ ). No, valja istaknuti da je u odnosu na 1981. godinu broj osoba sa završenom višom školom, fakultetom i umjetničkom akademijom povećan sa 14211 na 48401 ili 240,6\%. Pozitivno je, također, da je u istom razdoblju znatno smanjen broj osoba bez završenog ijednog razreda osnovne škole i s nezavršenom osnovnom školom (sa 262960 na 55534 ili za 78,9\%). Dio tog smanjenja valja tumačiti i biološkim razlozima, naime, činjenicom da su 1981. godine, bez škole i s nezavršenom osnovnom školom uglavnom bili stariji naraštaji, a koji dobrim dijelom 2011. više nisu bili među živima.

Istodobno, povećan je broj i udio stanovništva sa završenim osnovnoškolskim i srednjoškolskim obrazovanjem - porast broja stanovnika sa završenom osnovnom školom je iznosio $38,2 \%$, a sa srednjom školom $128,4 \%$. To znači da se u promatrana četiri desetljeća prosječna razina naobrazbe u sjeverozapadnoj Hrvatskoj znatno poboljšala što se, dakako, može i treba držati pozitivnim trendom u kontekstu daljnjeg društvenog i gospodarskog razvoja ovog područja.

Razmatrajući obrazovnu strukturu (stanovništvo s nezavršenom osnovnom školom s jedne strane te oni s završenim stručnim i sveučilišnim studijem s druge strane) po županijama, iz tablice 15 proizlazi da je 1981. godine u svim županijama bilo više od $50 \%$ stanovništva starog 15 godina i više koje nije završilo osnovnu školu. Najmanji udio takvih osoba imala je Varaždinska županija (50,8\%) dok je u Krapinsko-zagorskoj i Koprivničko-križevačkoj županiji taj udio iznosio čak i više $60 \%$. Do 2011. godine udio osoba s nezavršenom osnovnom školom znatno je pao u svim županijama, a Krapinsko-zagorskoj županiji s najnepovoljnijim udjelom, priključuje se Međimurska umjesto Koprivničko-križevačke županije. Do toga je ponajviše došlo zbog relativno brojnog porasta Roma u Međimurju između 1981. i 2011. godine, a koji često prekidaju školovanje prije završetka osnovne škole. ${ }^{3}$ Što se tiče osoba sa završenim visokim obrazovanjem, obje godine redoslijed među županijama bio je isti. Po udjelu najobrazovanijeg stanovništva odskače Varaždinska

2 U popisu stanovništva 2001, pod osobama s visokim obrazovanjem podrazumijevale su se osobe sa završenim stručnim studijem (završenom višom školom i I. stupnjem fakulteta), završenim sveučilišnim studijem (osobe sa završenim fakultetom ili umjetničkom akademijom kao i osobe s magisterijem znanosti koje se u popisu 2011. više zasebno ne prikazuju) te osobe s doktoratom znanosti.

3 U Međimurskoj županiji 1981. godine zabilježeno je 1139 Roma (1\% ukupnog stanovništva), a 2011. godine njihov broj povećan je na 5107 (4,5\% stanovništva Međimurske županije). 
Tablica 14. Stanovništvo sjeverozapadne Hrvatske staro 15 godina i više prema završenoj školi 1981.2011. godine

\begin{tabular}{|c|c|c|c|c|c|c|c|c|}
\hline \multirow{2}{*}{$\begin{array}{l}\text { Razina } \\
\text { završene škole }\end{array}$} & \multicolumn{2}{|c|}{1981.} & \multicolumn{2}{|c|}{1991.} & \multicolumn{2}{|c|}{2001.} & \multicolumn{2}{|c|}{2011.} \\
\hline & Aps. & $\%$ & Aps. & $\%$ & Aps. & $\%$ & Aps. & $\%$ \\
\hline Bez škole & 29507 & 6,3 & 18763 & 4,1 & 8068 & 1,7 & 5029 & 1,1 \\
\hline 1-3 razreda o.š. & 33023 & 7,1 & 22073 & 4,9 & 20528 & 4,4 & 5085 & 1,1 \\
\hline 4-7 razreda o.š. & 200430 & 42,9 & 149337 & 33,0 & 82003 & 17,4 & 45420 & 10,0 \\
\hline Osnovna škola & 88645 & 19,0 & 114625 & 25,3 & 127733 & 27,1 & 122544 & 27,0 \\
\hline Srednja škola & 99484 & 21,3 & 123826 & 27,3 & 196691 & 41,8 & 227179 & 50,1 \\
\hline Stručni studij* & 7735 & 1,7 & 11188 & 2,5 & 14048 & 3,0 & 21375 & 4,7 \\
\hline Sveučilišni studij** & 6476 & 1,4 & 8562 & 1,9 & 18934 & 4,0 & 26670 & 5,9 \\
\hline Doktorat znanosti*** & - & - & - & - & 175 & 0,04 & 356 & 0,08 \\
\hline UKUPNO & 467669 & 100 & 452760 & 100 & 470966 & 100 & 453800 & 100 \\
\hline
\end{tabular}

Razlika do ukupnog broja odnosi se na stanovnike s nepoznatom završenom školom.

*Obuhvaćene su sve više škole, I. (VI.) stupnjevi fakulteta te stručni studiji po Bologni.

** Obuhvaćeni su svi fakulteti, umjetničke akademije, svi sveučilišni studiji po Bologni te magistarski znanstveni, stručni i umjetnički studij.

***Objavljeni podaci popisa 1981. i 1991. ne pokazuju broj stanovnika s doktoratom znanosti

IZVOR: za 1981. interna baza DZS-a. Popis stanovništva 1991. Stanovništvo prema školskoj spremi, pismenosti i spolu po naseljima, Dokumentacija 884, DZS, 1994. Popis stanovništva 2001. Stanovništvo prema obrazovnim obilježjima, Statističko izvješće 1200, Zagreb, 2004. Popis stanovništva 2011. Stanovništvo staro 15 i više godina prema najvišoj završenoj školi, starosti i spolu, www.dzs.hr

županija, a slijede Koprivničko-križevačka, Međimurska te naposljetku Krapinskozagorska županija u kojoj 2011. godine udio visokoobrazovanog stanovništva nije još dosegao niti 10\% ukupnog stanovništva starog 15 godina i više.

Uspoređujući navedene udjele pojedinih županija s hrvatskim prosjekom 1981. godine vidljiv je znatno veći udio osoba s nezavršenom osnovnom školom te manji udio visokoobrazovanih osoba u svim županijama. Posljednjim popisom 2011. Koprivničko-križevačka te pogotovo Varaždinska županija imale su čak manji udio stanovništva s nezavršenom osnovnom školom od hrvatskog prosjeka, ali s druge strane sve županije i dalje bilježe znatno manji udio visokoobrazovanog stanovništva nego što je na državnoj razini. 
Tablica 15. Stanovništvo sjeverozapadne Hrvatske staro 15 godina i više s nezavršenom osnovnom školom i visokim obrazovanjem 1981. i 2011. godine

\begin{tabular}{|l|c|c|c|c|c|c|c|c|}
\hline \multirow{2}{*}{ Područje } & \multicolumn{4}{|c|}{ Nezavršena osnovna škola } & \multicolumn{4}{c|}{ Visoko obrazovanje } \\
\cline { 2 - 10 } & \multicolumn{2}{|c|}{1981.} & \multicolumn{2}{|c|}{2011.} & \multicolumn{2}{c|}{1981.} & \multicolumn{2}{c|}{2011.} \\
\cline { 2 - 10 } & Aps. & $\%$ & Aps. & $\%$ & Aps. & $\%$ & Aps. & $\%$ \\
\hline Kopr.-križ. ž. & 66679 & 61,6 & 9195 & 9,4 & 3033 & 2,8 & 10477 & 10,8 \\
\hline Krapinsko-zag. ž. & 74296 & 60,5 & 18765 & 16,6 & 2802 & 2,3 & 10431 & 9,2 \\
\hline Međimurska ž. & 47279 & 52,8 & 14490 & 15,3 & 2458 & 2,7 & 9592 & 10,1 \\
\hline Varaždinska ž. & 74706 & 50,8 & 13084 & 8,8 & 5918 & 4,0 & 17901 & 12,1 \\
\hline RH & 1651112 & 45,4 & 345959 & 9,5 & 231661 & 6,4 & 595233 & 16,4 \\
\hline
\end{tabular}

IZVOR: za 1981. interna baza DZS-a. Popis stanovništva 2011. Stanovništvo staro 15 i više godina prema najvišoj završenoj školi, starosti i spolu, www.dzs.hr

\section{ZAKLJUČAK}

Stanovništvo sjeverozapadne Hrvatske karakteriziraju dugoročni procesi ukupne i prirodne depopulacije te starenja stanovništva. Negativne tendencije $\mathrm{u}$ kretanju broja stanovnika nastavit će se i u tekućem međupopisnom razdoblju zbog dugotrajnih procesa prirodnog pada i starenja stanovništva te negativne migracijske bilance. Zbog dugoročnog karaktera demografskih promjena, zbog sve nepovoljnijih tendencija u razvoju stanovništva, te zbog njihova regresijskog učinka na društveno-gospodarski razvoj, potreban je neodgodiv, cjelovito promišljen i proveden aktivan koncept populacijske i obiteljske politike na razini države. To mora biti podržano stvaranjem pozitivnog društvenog ozračja ili raspoloženja za djecu, brak i obitelj, afirmiranjem odgovornog roditeljstva, gospodarskim rastom koji će omogućiti zapošljavanje, lakšim rješavanjem stambenog pitanja i nizom drugih poticajnih mjera populacijske i obiteljske politike iz domene radnog i poreznog zakonodavstva.

\section{LITERATURA}

1. Krešimir PERAČKOVIĆ i Nenad POKOS, „U starom društvu - Neki sociodemografski aspekti starenja u Hrvatskoj", Društvena istraživanja 127, god. 24, br. 1/2015, str. 89-110.

2. Alica WERTHEIMER-BALETIĆ, „Stanovništvo i razvoj“, MATE, Biblioteka Gospodarska misao, Zagreb, 1999, str. 660.

3. Dražen ŽIVIĆ, Nenad POKOS i Ivo TURK (2005): „Basic Demographic Processes in Croatia", Hrvatski geografski glasnik 67/2005, str. 27-44. 


\section{SAŽETAK}

\section{DEMOGRAFSKA OBILJEŽJA SJEVEROZAPADNE HRVATSKE}

U radu se analiziraju promjene osnovnih obilježja stanovništva sjeverozapadne Hrvatske. Broj stanovnika sjeverozapadne Hrvatske između 1900. i 2011. godine povećan je 8,5\%, a maksimum stanovništva zabilježen je 1953. godine. Od potonje godine broj stanovnika ovog područja konstantno se smanjuje te je posljednjim popisom 2011. zabilježeno 11,9\% stanovnika manje nego 1953. godine. Sagledavajući popisno kretanje broja stanovnika po županijama u tri karakteristična razdoblja (1900.-2011., 1948.-2011. i 2001.-2011.), uočava se izrazita bipolarnost jer Krapinsko-zagorska i Koprivničko-križevačka županija imaju pad broja stanovnika u sva tri razdoblja, dok Međimurska i Varaždinska županija bilježe brojčani porast u prva dva razdoblja, a pad broja stanovnika u razdoblju 2001.-2011. godine. Prirodno kretanje razmatrano je za razdoblje 1996.-2015. te je prirodnim putem u tih dvadeset godina sjeverozapadna Hrvatska izgubila 35 tisuća stanovnika dok se broj stanovnika izgubljen mehaničkim putem ne može utvrditi zbog promjena u metodologiji popisivanja ukupnog stanovništva nakon 1991. godine. Pokazatelji dobne strukture stanovništva sjeverozapadne Hrvatske također su izrazito nepovoljni jer je popisom 2011. zabilježeno 21,6\% stanovništva starog između 0 i 19 godina te 22,8\% stanovništva starog 60 godina i više. Iako se između 1981. i 2011. obrazovna struktura stanovništva sjeverozapadne Hrvatske znatno poboljšala, njezina obilježja još su uvijek ispod hrvatskog prosjeka te je posljednjim popisom zabilježeno svega 10,6\% visokoobrazovanog stanovništva starog 15 godina i više.

Ključne riječi: sjeverozapadna Hrvatska; stanovništvo; ukupna depopulacija; prirodni pad; demografsko starenje; obrazovna struktura.

\section{SUMMARY}

\section{DEMOGRAPHIC CHARACTERISTICS OF NORTHWESTERN CROATIA}

The paper analyzes the changes of the basic characteristics of the population of NorthWestern Croatia. Population of North-Western Croatia has increased by $8.5 \%$ between 1900 and 2011 and the maximum number of inhabitants was recorded in 1953. Since the latter year, the number of inhabitants of this area has been steadily decreasing, and the latest census in 2011 showed that the population decrease in comparison with 1953 was $11.9 \%$. Considering the census dynamics of the number of inhabitants per county in three characteristic periods (1900-2011, 1948-2011 and 2001-2011), the significant bipolarity was noticed. Krapina-Zagorje County and Koprivnica-Križevci County have a population decline, while the counties of Međimurje and Varaždin recorded a significant population increase in the first two periods and the population decline in the period 2001-2011. The natural population dynamics was researched for the period 1996 - 2015. In those twenty years North-Western Croatia has lost 35 thousand inhabitants by natural population drop (more deaths than births), while the population drop caused by emigration can not be determined due to changes in the methodology 
of censuses after 1991. Indicators of the age structure of North-Western Croatia are also extremely unfavourable. The 2011 census showed that $21.6 \%$ of the population was aged between 0 and 19 years and $22.8 \%$ of the population was aged 60 years and over. Although between 1981 and 2011 the educational structure of the North-Western Croatia population was improved considerably, its characteristics are still below the Croatian average. The latest population census from 2011 showed that there was only $10.6 \%$ of the highly educated population aged 15 years and more.

Key Words: North-Western Croatia; population; total depopulation; natural decline; demographic ageing; educational structure. 